\title{
Ethnobotany and antioxidant evaluation of commercialized medicinal plants from the Brazilian Pampa
}

\author{
Marianne Pinheiro Teixeira', Litiele Cruz ${ }^{2}$, Jeferson Luis Franco ${ }^{3}$, Renara Bittencourt Vieira' and Valdir Marcos Stefenon ${ }^{1 *}$
}

Received: June 6, 2015

Accepted: October 19, 2015

\begin{abstract}
Despite the importance of medicinal plants for the healthcare of local people, the knowledge about medicinal species used in the Pampa biome has been neglected over the years. In this study, an ethnobotanical survey was employed aiming to characterize the species richness and diversity of commercialized medicinal plant species in five cities within the Brazilian Pampa. Additionally, among the listed plants, ten species were selected for in vitro testing of their potential antioxidant activity. A total of 56 plant species belonging to 33 botanical families were listed by the 115 interviewees. No significant difference in commercialized medicinal plant species, and very similar species richness was observed among the cities, indicating that the local knowledge is consistently preserved across the studied cities. According to the biochemical analysis, Sphagneticola trilobata, Malva parviflora and Struthanthus flexicaulis emerged as very promising species for antioxidant activity. Further studies are recommended to advance our knowledge about the richness of medicinal plant species in the Brazilian Pampa, and to assess their therapeutic potential.
\end{abstract}

Keywords: ethnobiology, ethnopharmacology, gaúcho, oxidative stress, Pampa biome

\section{Introduction}

Tropical forest is believed to be home of many important and undiscovered medicinal plants that may hold the key for the treatments of diseases such as AIDS and cancer (Stepp \& Moermann 2001). While it is much probable that several important new drugs remain hidden in plants from the species rich tropical forests (such as the Amazonian and Atlantic Forests, in Brazil), they may also lie hidden in other less studied biomes, as the Brazilian Pampa. While the Atlantic Forest is widely investigated concerning biodiversity and its potential uses (Ritter et al. 2015), the Brazilian Pampa is one of the most fragile, unprotected and less known environments in Brazil, even though a very rich biodiversity is expected for this region (Roesch et al. 2009).
In a recent bibliometric study of ethnobotanical research in Brazil, Ritter et al. (2015) revealed a very low number of studies performed in the Pampa biome concerning this topic. According to the research parameters, only two out of 258 ethnobotanical studies published between 1988 and 2013 were performed in the Pampa biome.

The investigation of the ethnobotanical knowledge in the Pampean domain is important in order to fill a gap related to the use of plant resources from this biome. The people living in the Brazilian Pampa sensu stricto have incorporated the nature in their culture and implemented an extractive system strongly based on a mix of Portuguese, Spanish, Argentinian and Uruguayan traditions (Suertegaray \& Silva 2009; Roesch et al. 2009). Brazilian Pampa sensu stricto corresponds to the area of the biome primarily dominated by a steppic-savanna

\footnotetext{
${ }^{1}$ Research Group on Ecological Dynamic and Diversity in Forest Ecosystems, Universidade Federal do Pampa, Campus São Gabriel, 97300-000, São Gabriel, RS, Brazil

${ }^{2}$ Department of Chemistry, Universidade Federal de Santa Maria, 97105-900, Santa Maria, RS, Brazil

${ }^{3}$ Oxidative Stress and Cell Signaling Research Group, Universidade Federal do Pampa, Campus São Gabriel, 97300-000, São Gabriel, RS, Brazil

*Corresponding author: valdirstefenon@unipampa.edu.br
} 
environment and with a long tradition of cattle ranching and crop plantations (Lemos et al. 2014). Although the influence of other cultures is not discarded (see Materials and Methods), the ethnobotanical knowledge of the Pampean people is expected to differ from traditional communities with stronger influence of African cultures, as in the Cerrado and Caatinga biomes, in the Northeast Brazil (e.g. Albuquerque 2001). In addition, the plant species occurring in the Brazilian Pampa differ from other biomes and need to have their uses elucidated.

Investigating the ethnobotanical knowledge of riverside communities in two localities within the Brazilian Pampa, Costella et al. (2013) found medicinal plants as the second most important use given to local vegetation. Despite the significant advances observed in modern medicine, plants still play an important role in healthcare, mainly in developing countries. For instance, natural antioxidants derived from plants, either in the form of raw extracts or their chemical constituents, are accepted to be very effective preventing the deleterious processes caused by oxidative stress (Cruz et al. 2014).

Substantial evidences have been accumulated and indicate that numerous disorders and diseases are caused by reactive oxygen species and other oxidant agents. Therefore, researchers have focused on the identification of antioxidant agents for prevention and treatment of several diseases. Antioxidant agents stabilize or deactivate free radicals, usually avoiding they reach targets in biological cells (Saeed et al. 2012). As a consequence of its multitude and magnitude of activities, an increasing interest in naturally occurring antioxidants for use in food, cosmetic and pharmaceutical products is observed (Saeed et al. 2012). Studies on different plant species have indicated the presence of antioxidant agents such as phenolics, flavonoids and tannins, so that the ingestion of these antioxidant contents of medicinal plants may contribute to the natural body protection against diseases (Saeed et al. 2012).

Considering the scarcity of knowledge about ethnobotany of the Pampa biome and that the study of popular medicinal plants has made significant contributions to the theoretical development of the ethnopharmacology (Heinrich \& Gibbons 2001), this study aimed to answer three main questions: (1) Which are the most important medicinal plants commercialized in the Brazilian Pampa sensu stricto? (2) Is there a significant difference of medicinal plant species commercialized in cities of the Pampa sensu stricto? (3) Are there some novel species with important antioxidant activity among the commercialized medicinal plants? In order to answer these questions, we performed an ethnobotanical survey in five cities located within the Brazilian Pampa sensu stricto, and achieved in vitro biochemical assays with plants selected among the species listed by the informants who joined the study.

\section{Materials and Methods}

\section{Characterization of the Pampean people}

The people of the Brazilian Pampa, the so called "Gaúchos", developed a strong tradition based on livestock and agriculture, which is reflected in the established habits, costumes and daily practices of various communities. These people incorporated the nature in their culture and implemented an extractive system essentially based on natural resources. This system was based upon intuition and common sense methodologies from previous knowledge brought by immigrants (most of the colonizers of the Brazilian Pampa were from Spanish and Portuguese origin) or from the daily in the field, with great influence from Argentinian and Uruguayan cultures (Roesch et al. 2009). In addition, the indigenous culture of the "Charrua" tradition also personifies the Pampean people (Suertegaray \& Silva 2009). Natives from this group were engaged in the work of the first European farms established in the Brazilian Pampa and integrated their knowledge to the culture of the Pampean people (Suertegaray \& Silva 2009). African elements were also integrated to the local culture through the slaves and their descendants, although in a minor intensity (Pereira 2014).

\section{The study area}

The Brazilian Pampa is located between latitudes $28^{\circ} 00^{\prime} \mathrm{S}$ and $34^{\circ} 00^{\prime} \mathrm{S}$ and longitudes $49^{\circ} 30^{\prime} \mathrm{W}$ and $58^{\circ} 00^{\prime}$ W, covering about of $63 \%$ of the Rio Grande do Sul State (Fig. 1). The biome lies within the South Temperate Zone and has both subtropical and temperate climates with four well-characterized seasons. The Brazilian Pampa sensu stricto is composed by a mosaic of vegetation, dominated by grasslands, with sparse shrub and tree formations, covering the western portion of the biome (Lemos et al. 2014). Historically, forest cover in the Brazilian Pampa remains constrained to formations along river margins and nucleations within the grassland formations. Essentially, this structure is result of the grassland resilience and of human interference through expansion of agriculture, ranching and monoculture forestry with exotic species (Lemos et al. 2014). The soil of the Brazilian Pampa is naturally fragile, and its intense degradation has contributed to a socio-economic fragility as evidenced by the low Social Development Index of the region (Roesch et al. 2009).

\section{Ethnobotanical survey}

The ethnobotanical survey was performed within the Brazilian Pampa sensu stricto from April to November 2014. Using a purposive sampling strategy (Bernard 2006), a total of 115 medicinal plant vendors were interviewed in the cities of São Gabriel (62,692 inhabit- 


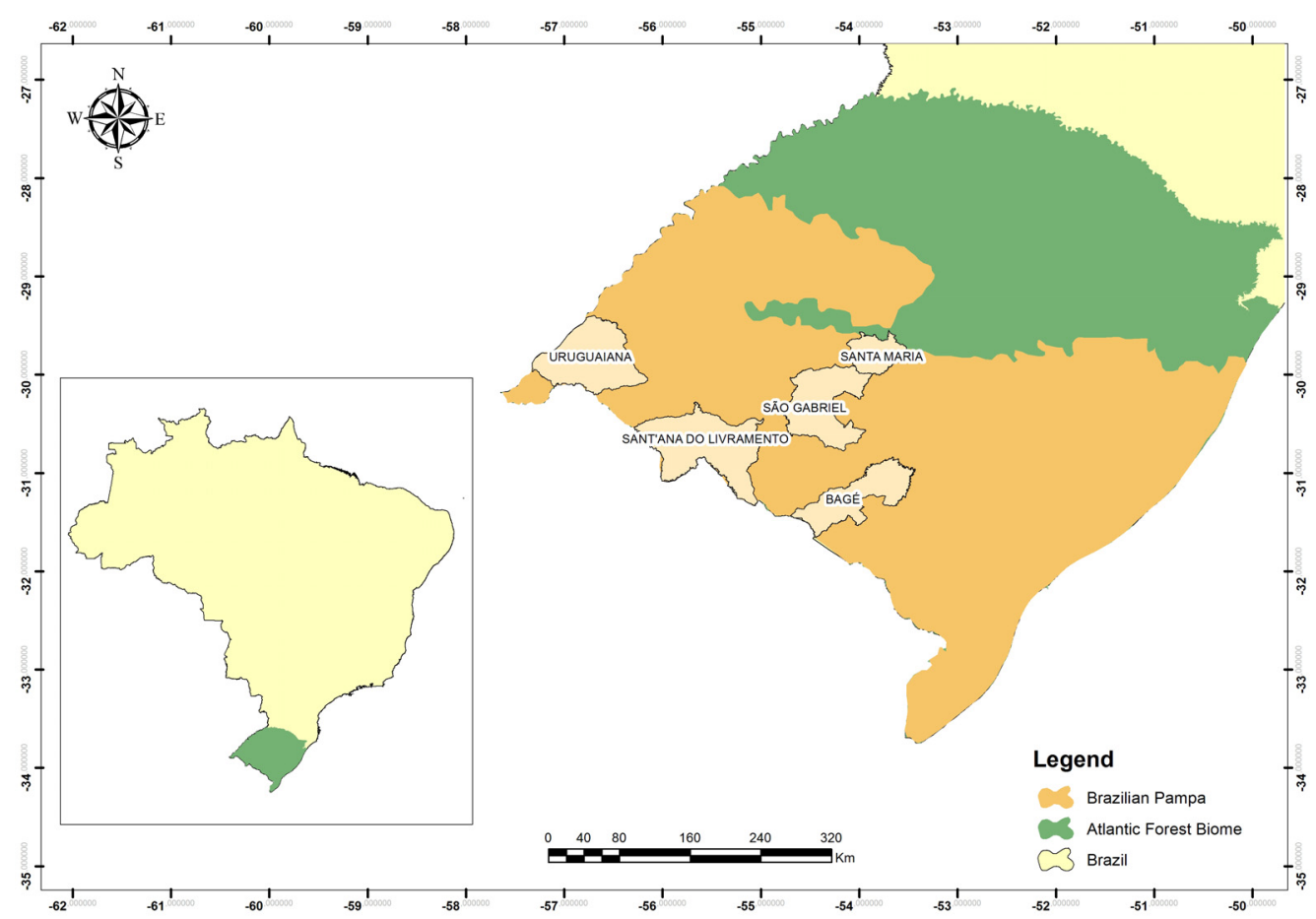

Figure 1. Location of the Brazilian Pampa biome in Southern Brazil and of the five cities where this study was performed.

ants; 10 informants), Santana do Livramento (83,324 inhabitants; 15 informants), Bagé (121,500 inhabitants; 20 informants), Uruguaiana (129,580 inhabitants; 30 informants) and Santa Maria (274,838 inhabitants; 40 informants). In order to assess the information about commercialized medicinal plants in a similar magnitude in all cities, we relativized the number of informants through a proportionate stratified random sample (Bernard 2006), interviewing about one informant for each 6,000 to 7,000 inhabitants. Using this approach we intend to minimize bias in the diversity indexes estimated, since the proportion of informants will be similar across cities, independent of the population size. All informants were initially informed about the aims of the research. Only the informants who agreed in cooperating with the study and that signed a participatory term were interviewed, according to the project submitted to the Committee of Ethics in Research of the Universidade Federal do Pampa (case number 18663313). Semi-structured interviews were conducted with the participants, starting with the main question: "Which medicinal plants do you sell?" From this question, information about illnesses treated and parts of plant utilized was also recorded.

Information about commercialized medicinal plants was obtained from street-sellers (person who sell medicinal plants along the street, also known as "erveiros", "raizeiros", among others), free-markets (places where medicinal plants, fruits, crops, honey and other natural products are sold by their own producers) and drugstores, by listing all plants commercialized exclusively as medici- nal (food and condiments were not included in the list). In drugstores, the interviewed informants were asked to list only non-industrialized plants commercialized. Drugstores were selected in order to cover the largest area of the city (downtown and neighborhoods) and avoiding information from stores of the same drugstores group. Street-sellers were selected using the snowball method (Bernard 2006), starting with the indication of the first informant by a citizen of the city known to recognize such individuals and finishing when the expected sample size of the purposive sampling was reached. Similarly to the street-sellers, freemarkets were identified through information obtained from a citizen known to recognize such places. The popular name, the recommended application and the used part of these plants were recorded exactly as informed from each participant of the survey.

Usually, the medicinal plants are commercialized in a dry, pulverized, or fragmented form or even as parts of the plants (seeds, roots, leaves or barks), not enabling the correct identification of the species (Albuquerque et al. 2007). In order to avoid erroneous identification of the commercialized medicinal plants, the cited species were collected from homegardens of some street-sellers and the specimens were identified with the help of specialized literature (floras and monographs) and with assistance of botanists, following the International Plants Names Index (www.ipni.org) and The Plant List platform (www. theplantlist.org). Considering that the popular name of the plants could differ among cities or even among informants, samples of the commercialized plants were obtained from 
each informant and compared with the plants collected in the home gardens of street-sellers from the city of São Gabriel. All species were obtained from street-sellers, including plants not commercialized by this group, as some species recorded just in the drugstores. Voucher specimens of the collected plant species were deposited in the Herbarium Bruno Edgar Irgang (HBEI) of the Universidade Federal do Pampa, Campus São Gabriel.

\section{Characterization of the most important commercialized plant species}

Assuming that the most commercialized species are judged by the local people as the most important ones, the quoted importance of each species was computed for each city based on the number of occurrences in the list, using the importance value of each category as $I V_{\text {cat }}=$ cat/ tot and the importance value of each species within each category as $I V_{s p / c a t}=s p / c a t$ (Costella et al. 2013), where:

$I V_{\text {cat }}=$ importance value of the category,

$I V_{s p / c a t}=$ importance value of the species within the category,

tot $=$ total of citations,

$c a t=$ number of times the category was cited,

$s p=$ number of times the species was cited within the category.

\section{Characterization of the difference of medicinal plant species commercialized in each city}

The difference of medicinal plant species commercialized in cities of the Pampa biome was determined using different strategies.

Similarity of listed species between cities was determined using the Jaccard's index of similarity $J=c /(a+b+c)$ according to Real \& Vargas (1996), where:

$a=$ the number of plants cited in the first city but not in the second,

$b=$ the number of plants cited in the second city but not in the first one, and

$c=$ the number of plants cited in both cities.

This index allows quantifying the amount of difference for each pair of cities. It is based only on the species commercialized in at least one city, excluding plant species not cited for the cities considered.

A Veen's diagram (Veen 1880) based on the list of commercialized plants was draw in order to visualize the species shared among localities. These analyses enable to evaluate the difference of medicinal species commercialized among the cities. Veen's diagram was drawn using the on line Veen Diagram software of the Bioinformatics \& Evolutionary Genomics group of the Gent University (http://bioinformatics.psb.ugent.be/webtools/Venn/).
The diversity of species listed in each city was computed using the Shannon's index of diversity as $H^{\prime}=-\Sigma\left(p_{i} \mathrm{X} \log _{2 p i}\right)$ (Shannon 1948), where:

$p_{i}=$ the relative frequency of citations of each species within the studied site, and

$\log _{2} p_{i}=$ the base 2 logarithm of $p_{i}$.

Different from the absolute number of plant species listed, that gives the same importance for species cited just once or cited tens of times, the Shannon's index considers the frequency of citations. Therefore, higher values of Shannon's index of diversity are obtained in cities with more homogeneous number of citations for different species, while the absolute number of species listed has a secondary weight in the comparisons. This excludes the false perception given by species cited by a single informant and, therefore, with low importance for the whole city and allows quantifying the richness of commercialized medicinal plants of the studied cities. The evenness index was computed as $E=H_{\max } / H^{\prime}$, where $H_{\max }$ is the $\log _{2}$ of the number of species cited in each city. This index determines the uniformity of the cited species, in relation to the frequency of citations.

A multivariate analysis (Principal Component Analysis, PCA) was employed to evaluate the relationship among cities relative to the species richness and frequency each species was cited. Computations of the correlation among populations and plotting of the results were performed using the software PAST 3.04 (Hammer et al. 2001).

In order to investigate the richness of knowledge of medicinal plants among the informants, the knowledge richness index (KRI) was calculated as $K R I=1 \Sigma J i^{2}$ (Araújo et al. 2012), where: and

$R_{i}$ is the record of species mentioned by the informant

$R_{u i}$ is the total record of species mentioned in each city.

This index enables the comparison among informant groups regarding their knowledge and its unique qualities. The KRI values range from 0 to infinity, with lower values indicating a higher knowledge of medicinal plants by the group of informants. In addition, the Jaccard's index was employed to quantify the pairwise similarity between groups of informants, concerning the medicinal species cited.

\section{Identification of novel species with important antioxidant activity}

Antioxidants are compounds with protective action against free radicals, minimizing tissue injury in human diseases such as heart diseases, gastric ulcers, and decline in brain functions and immune system. Based on the infor- 
mation obtained after the ethnobotanical survey, species having medicinal proprieties related to the immune system (e.g. urinary and respiratory infections), gastrointestinal and cardiac diseases, and on the absence of studies related to their antioxidant activity in the specialized literature, ten species were selected for the biochemical analyses: Sphagneticola trilobata (L.) Pruski, Gochnatia polymorpha (Less.) Cabrera, Bauhinia forficate Link, Maytenus ilicifolia Mart. ex Reissek, Equisetum sp L., Salvia officinalis L., Struthanthus flexicaulis Mart., Malva parviflora L., Rumex obtusifolius L. and Muehlenbeckia sagittifolia (Ortega) Meisn. Samples of these species where obtained from informants and evaluated in vitro, in order to determine their potential antioxidant activity.

Leaf samples from each species were collected and dried during 12 hours at $40^{\circ} \mathrm{C}$. The dried samples were crushed individually using a TissueLyser grind mill (Qiagen, Germany). Some rigid samples were frozen in liquid nitrogen prior to crushing. For each species, extracts were prepared with $1.0 \mathrm{~g}$ of grinded leaves left during $10 \mathrm{~min}$ in $10 \mathrm{~mL}$ boiling water. After this period, plant extracts were filtered and separately stored for the biochemical analyses. All the spectrophotometric assay of the analysis of antioxidant properties was performed in an Agilent Cary 60 UV-VIS spectrophotometer and a Perkin Elmer Enspire multimode plate reader.

Folin-Ciocalteu reagent, 2,2'-azino-bis(3-ethylbenzothiazoline-6-sulfonic acid) diammonium salt (ABTS), and 2,4,6-tris (2-pyridyl)-5-triazine (TPTZ) were purchased from Sigma-Aldrich (São Paulo, SP, Brazil). Fe(II) ammonium sulfate hexahydrate, gallic acid monohydrate, aluminum chloride hexahydrate, potassium persulfate, and iron(III) chloride were purchased from Vetec Química Fina Ltda. (Rio de Janeiro, RJ, Brazil). All the other chemicals used in this work were of analytical grade.

The antioxidant activity of the plants was determined according to the method of Baltrušaityte et al. (2007) with minor modifications. Radical solution was generated by oxidation of solutions prepared with $1 \mathrm{~mL}$ of $7 \mathrm{mM}$ ABTS [2,2'-azino-bis(3-ethylbenzothiazoline-6-sulfonic acid) diammonium salt] stock solution and $17.5 \mu \mathrm{L}$ of $140 \mathrm{mM}$ potassium persulfate $\left(\mathrm{K}_{2} \mathrm{~S}_{2} \mathrm{O}_{8}\right) .200 \mu \mathrm{L}$ of solution was mixed with $10 \mu \mathrm{L}$ of plant extract solution $(10 \mathrm{mg} / \mathrm{mL})$ in a microplate and the decrease in the absorbance was measured after $10 \mathrm{~min}$. Ascorbic acid $(20 \mu \mathrm{g} / \mathrm{mL})$ was used as a positive control and the radical scavenging activity (RSA) was calculated as $\% R S A=\left[A_{0}-A_{1} / A_{0}\right] \mathrm{X} 100$, where $A_{0}$ is the absorbance of the control reaction and $A_{1}$ is the absorbance of the plant extract.

The reducing capacity of the plant extracts was assayed with the original method of Benzie \& Strain (1996), mixing $9 \mu \mathrm{L}$ of plant extract $(100 \mathrm{mg} / \mathrm{mL})$ with $270 \mu \mathrm{L}$ of freshly prepared FRAP (ferric reducing antioxidant power) reagent. The FRAP reagent contained $2.5 \mathrm{~mL}$ of $0.3 \mathrm{M}$ acetate buffer $\mathrm{pH} 3.6$ with $250 \mu \mathrm{L}$ of $10 \mathrm{mM}$
2,4,6-Tris(2-pyridyl)-s-triazine (TPTZ) solution and $250 \mu \mathrm{L}$ of $\mathrm{FeCl} 3 \cdot 6 \mathrm{H}_{2} \mathrm{O}$. The mixture was shaken and left in a water bath for $30 \mathrm{~min}$ and the absorbance readings were taken at $595 \mathrm{~nm}$. Fe(II) ammonium sulfate hexahydrate was used to calculate the standard curve $(100-2000 \mu \mathrm{M})$. The reducing ability of plant extract was expressed as $\mu \mathrm{M}$ of Fe(II) equivalent/100g plant extract.

Phenolic compounds from plant extracts were detected by the method of Folin-Ciocalteu (Singleton et al. 1998) with minor modifications. Briefly, $4 \mu \mathrm{L}$ plant extract $(100 \mathrm{mg} / \mathrm{mL})$ was mixed with $35 \mu \mathrm{L} 1 \mathrm{~N}$ Folin-Ciocalteu's reagent. After $3 \mathrm{~min}, 70 \mu \mathrm{L} 15 \% \mathrm{Na}_{2} \mathrm{CO}_{3}$ solution was added to the mixture and adjusted to $284 \mu \mathrm{L}$ with ultrapure water. The reaction was kept in the dark for $2 \mathrm{~h}$, after which the absorbance was read at $760 \mathrm{~nm}$. Gallic acid was used as standard (30, 50, 100, 200, 300, 400, 500 e $600 \mu \mathrm{g} / \mathrm{mL})$. The results were expressed as $\mathrm{mg}$ of gallic acid equivalents (GAEs) per $100 \mathrm{~g}$ plant extract.

The total flavonoid content was determined using the Dowd method, adapted by Arvouet-Grand et al. (1994). Briefly, $150 \mu \mathrm{L}$ of $2 \%$ aluminium trichloride $\left(\mathrm{AlCl}_{3}\right)$ was mixed with the same volume of plant extract $(10 \mathrm{mg} / \mathrm{mL})$. The blank consisted of $150 \mu \mathrm{L}$ plant extract with $150 \mu \mathrm{L}$ methanol without $\mathrm{AlCl}_{3}$. The absorbance was read at $510 \mathrm{~nm}$ and quercetin was used as standard $(0-25 \mu \mathrm{g} / \mathrm{mL})$. The results were expressed as $\mathrm{mg}$ of quercetin equivalents (QE) per gram of plant extract.

\section{Results}

\section{The most important commercialized plant species}

Fifty-six plant species belonging to 33 botanical families were listed by the 115 interviewed informants (Tab. 1). Twenty-seven plant species were listed exclusively from street-sellers, 10 only from drugstores, 11 species were cited by street-sellers and in drugstores and eight species were cited by street-sellers, in drugstores and in freemarkets (Tab. 1). Family Asteraceae was the most significant considering the number of species cited (10 species), followed by Lamiaceae (seven species). Fifty-four species were cited in São Gabriel, 46 in Santana do Livramento, 41 in Bagé, 54 in Uruguaiana and 50 in Santa Maria. Plants were grouped into categories (Tab. 2) according to the medicinal uses indicated by the informants: respiratory diseases (RSD), urinary infections (URI), gastrointestinal diseases (GID), cardiac diseases (CDD), analgesics or anti-inflammatory (AAI), sedative (SED), weight control (WGC), laxative (LXT), healing (HEA) and against sexual impotence (ASI).

The most frequently use referred by the informants was for species against gastrointestinal diseases, with importance value $I V_{G I D}=0.341$, followed by plants against 
Table 1. Ethnobotanical use and absolute frequency of citations of each species in São Gabriel (SG), Santana do Livramento (SL), Bagé (BG), Santa Maria (SM) and Uruguaiana (UR). Estimations of Shannon's index of diversity $\left(H^{\prime}\right)$ and Eveness index $(E)$ are also presented for each city.

\begin{tabular}{|c|c|c|c|c|c|c|c|c|c|}
\hline \multirow{2}{*}{ Family/species } & \multirow{2}{*}{$\begin{array}{c}\text { Medicinal } \\
\text { use' }^{\prime}\end{array}$} & \multirow{2}{*}{$\begin{array}{l}\text { Plant part(s] } \\
\text { used }\end{array}$} & \multirow{2}{*}{ Informants ${ }^{2}$} & \multicolumn{6}{|c|}{ Absolute frequency of citations } \\
\hline & & & & SG & SL & BG & SM & UR & Total \\
\hline \multicolumn{10}{|l|}{ Alismataceae } \\
\hline Echinodorus grandiflorus (Cham. \& Schltdl.) Micheli & $\mathrm{CDD}$ & Leaves & SS & 2 & 0 & 3 & 3 & 0 & 8 \\
\hline \multicolumn{10}{|l|}{ Aloaceae } \\
\hline Aloe arborescens Mill & HEA & Leaves & SS & 4 & 3 & 3 & 6 & 4 & 20 \\
\hline \multicolumn{10}{|l|}{ Amaranthaceae } \\
\hline Alternanthera paronichyoides A. St.-Hil. & AAI & $\begin{array}{l}\text { Leaves and } \\
\text { branches }\end{array}$ & SS & 3 & 1 & 4 & 5 & 1 & 14 \\
\hline \multicolumn{10}{|l|}{ Annonaceae } \\
\hline Annona muricata $\mathrm{L}$. & GID & Leaves & SS & 1 & 0 & 0 & 2 & 1 & 4 \\
\hline \multicolumn{10}{|l|}{ Apiaceae } \\
\hline Foeniculum vulgare Hill. \& Mill & GID & $\begin{array}{l}\text { Fruits and } \\
\text { seeds }\end{array}$ & D & 6 & 6 & 4 & 5 & 12 & 31 \\
\hline \multicolumn{10}{|l|}{ Asteraceae } \\
\hline Achyrocline satureioides DC. & GID & $\begin{array}{l}\text { Leaves and } \\
\text { flowers }\end{array}$ & D, SS & 2 & 3 & 3 & 8 & 13 & 29 \\
\hline Sphagneticola trilobata (L.) Pruski & AAI & Leaves & D, SS & 4 & 5 & 5 & 7 & 5 & 26 \\
\hline Mikania glomerata Spreng. & RSD & Leaves & D, SS, FM & 4 & 5 & 4 & 6 & 7 & 26 \\
\hline Matricaria chamomilla $\mathrm{L}$. & SED & Flowers & D, SS & 5 & 4 & 3 & 5 & 12 & 29 \\
\hline Gochnatia polymorpha (Less.) Cabrera & RSD & $\begin{array}{l}\text { Leaves and } \\
\text { stem bark }\end{array}$ & SS & 3 & 3 & 1 & 3 & 2 & 12 \\
\hline Cynara scolymus L. & URI & $\begin{array}{l}\text { Leaves, flowers } \\
\text { and roots }\end{array}$ & SS & 1 & 1 & 0 & 2 & 2 & 6 \\
\hline Calendula officinalis $\mathrm{L}$. & HEA & Whole plant & D, SS & 2 & 1 & 0 & 0 & 2 & 5 \\
\hline Baccharis trimera (Less.) DC. & GID & Leaves & D, SS, FM & 6 & 4 & 7 & 10 & 9 & 36 \\
\hline Artemisia absinthium L. & GID & $\begin{array}{l}\text { Leaves and } \\
\text { branches }\end{array}$ & SS & 3 & 4 & 4 & 6 & 1 & 18 \\
\hline Arctium lappa L.\& Kalm & LXT & Leaves & SS & 2 & 0 & 1 & 0 & 1 & 4 \\
\hline \multicolumn{10}{|l|}{ Boraginaceae } \\
\hline Cordia ecalyculata Vell. & WGC & Leaves & D & 1 & 1 & 0 & 0 & 3 & 5 \\
\hline \multicolumn{10}{|l|}{ Caesalpiniaceae } \\
\hline Bauhinia forficata Link & URI & Leaves & SS & 3 & 2 & 2 & 4 & 3 & 14 \\
\hline \multicolumn{10}{|l|}{ Caprifoliaceae } \\
\hline Sambucus nigra L. \& Marshall & WGC & $\begin{array}{l}\text { Leaves and } \\
\text { stem bark }\end{array}$ & SS & 2 & 3 & 2 & 4 & 2 & 13 \\
\hline \multicolumn{10}{|l|}{ Celastraceae } \\
\hline Maytenus ilicifolia Mart. ex Reissek & GID & Leaves & D, SS & 4 & 5 & 3 & 4 & 1 & 17 \\
\hline \multicolumn{10}{|l|}{ Chenopodiaceae } \\
\hline Chenopodium ambrosioides $\mathrm{L}$. & GID & $\begin{array}{l}\text { Leaves and } \\
\text { branches }\end{array}$ & SS & 3 & 2 & 4 & 6 & 2 & 17 \\
\hline \multicolumn{10}{|l|}{ Equisetaceae } \\
\hline Equisetum sp L. & URI & Whole plant & D, SS & 2 & 1 & 0 & 2 & 1 & 6 \\
\hline \multicolumn{10}{|l|}{ Euphorbiaceae } \\
\hline Euphorbia serpens Kunth & URI & Whole plant & D, SS, FM & 5 & 4 & 6 & 7 & 3 & 25 \\
\hline
\end{tabular}


Table 1. Continuation.

\begin{tabular}{|c|c|c|c|c|c|c|c|c|c|}
\hline \multirow{2}{*}{ Family/species } & \multirow{2}{*}{$\begin{array}{l}\text { Medicinal } \\
\text { use }^{1}\end{array}$} & \multirow{2}{*}{$\begin{array}{l}\text { Plant part[s] } \\
\text { used }\end{array}$} & \multirow{2}{*}{ Informants ${ }^{2}$} & \multicolumn{6}{|c|}{ Absolute frequency of citations } \\
\hline & & & & SG & SL & BG & SM & UR & Total \\
\hline \multicolumn{10}{|l|}{ Fabaceae } \\
\hline Parapiptadenia rigida (Benth.) Brenan & RSD & $\begin{array}{l}\text { Stem bark, } \\
\text { stem and } \\
\text { branches }\end{array}$ & D, SS & 4 & 2 & 2 & 3 & 3 & 14 \\
\hline Senna alexandrina Mill. & LXT & Leaves & $\mathrm{D}$ & 0 & 1 & 3 & 2 & 4 & 10 \\
\hline \multicolumn{10}{|l|}{ Illiciaceae } \\
\hline Illicium verum Hook.f. & RSD & Fuits & D & 2 & 0 & 0 & 1 & 2 & 5 \\
\hline \multicolumn{10}{|l|}{ Lamiaceae } \\
\hline Rosmarinus officinalis L. & GID & $\begin{array}{l}\text { Leaves and } \\
\text { branches }\end{array}$ & D, SS, FM & 4 & 3 & 5 & 10 & 6 & 28 \\
\hline Plectranthus barbatus Andrews & GID & Leaves & D, SS, FM & 5 & 4 & 6 & 9 & 8 & 32 \\
\hline Mentha sp L. & GID & Leaves & D, SS, FM & 2 & 4 & 5 & 7 & 10 & 28 \\
\hline Melissa officinalis L. & SED & Leaves & D, SS, FM & 2 & 2 & 2 & 4 & 3 & 13 \\
\hline Lavandula officinalis Chaix & GID & Leaves & $\mathrm{D}$ & 1 & 1 & 3 & 6 & 1 & 12 \\
\hline Cunila microcephala Benth. & RSD & $\begin{array}{l}\text { Leaves and } \\
\text { branches }\end{array}$ & D, SS & 3 & 4 & 5 & 6 & 4 & 22 \\
\hline Salvia officinalis $\mathrm{L}$. & RSD & Leaves & D, SS & 2 & 1 & 1 & 4 & 3 & 11 \\
\hline \multicolumn{10}{|l|}{ Loranthaceae } \\
\hline Struthanthus flexicaulis Mart. & $\mathrm{CDD}$ & Leaves & SS & 3 & 1 & 2 & 2 & 7 & 15 \\
\hline \multicolumn{10}{|l|}{ Malvaceae } \\
\hline Luehea divaricata Mart. & RSD & $\begin{array}{l}\text { Stem bark and } \\
\text { flowers }\end{array}$ & SS & 2 & 4 & 2 & 3 & 2 & 13 \\
\hline Malva parviflora $\mathrm{L}$. & URI & $\begin{array}{l}\text { Leaves and } \\
\text { roots }\end{array}$ & SS & 3 & 1 & 2 & 6 & 5 & 17 \\
\hline \multicolumn{10}{|l|}{ Meliaceae } \\
\hline Trichilia catigua A. Juss. & ASI & $\begin{array}{l}\text { Leaves and } \\
\text { branches }\end{array}$ & $\mathrm{D}$ & 1 & 1 & 0 & 1 & 4 & 7 \\
\hline \multicolumn{10}{|l|}{ Musaceae } \\
\hline Musa paradisiaca $\mathrm{L}$. & RSD & Inflorescence & SS & 2 & 1 & 1 & 3 & 4 & 11 \\
\hline \multicolumn{10}{|l|}{ Myrtaceae } \\
\hline Blepharocalyx salicifolius (Kunt.) O.Berg & GID & Leaves & SS & 1 & 0 & 0 & 0 & 2 & 3 \\
\hline Eugenia uniflora L. & GID & Leaves & SS & 3 & 2 & 4 & 4 & 2 & 15 \\
\hline Eucalyptus sp L'Hér. & RSD & $\begin{array}{l}\text { Leaves and } \\
\text { flowers }\end{array}$ & SS & 1 & 0 & 3 & 4 & 2 & 10 \\
\hline Campomanesia xanthocarpa O.Berg & WGC & Leaves & D, SS & 1 & 0 & 0 & 0 & 2 & 3 \\
\hline \multicolumn{10}{|l|}{ Oleaceae } \\
\hline Olea europaea L. & WGC & Leaves & SS & 0 & 1 & 0 & 1 & 0 & 2 \\
\hline \multicolumn{10}{|l|}{ Passifloraceae } \\
\hline Passiflora alata Curtis & SED & Leaves & D, SS, FM & 1 & 3 & 3 & 4 & 4 & 15 \\
\hline \multicolumn{10}{|l|}{ Piperaceae } \\
\hline Piper umbellatum L. & GID & $\begin{array}{l}\text { Leaves, roots, } \\
\text { stem bark }\end{array}$ & SS & 1 & 0 & 1 & 1 & 1 & 4 \\
\hline \multicolumn{10}{|l|}{ Plantaginaceae } \\
\hline Plantago major $\mathrm{L}$. & RSD & Leaves & SS & 3 & 2 & 4 & 7 & 3 & 19 \\
\hline
\end{tabular}


Table 1. Continuation.

\begin{tabular}{|c|c|c|c|c|c|c|c|c|c|}
\hline \multirow{2}{*}{ Family/species } & \multirow{2}{*}{$\begin{array}{c}\text { Medicinal } \\
\text { use }^{\prime}\end{array}$} & \multirow{2}{*}{$\begin{array}{l}\text { Plant part[s] } \\
\text { used }\end{array}$} & \multirow{2}{*}{ Informants ${ }^{2}$} & \multicolumn{6}{|c|}{ Absolute frequency of citations } \\
\hline & & & & SG & SL & BG & SM & UR & Total \\
\hline \multicolumn{10}{|l|}{ Poaceae } \\
\hline Cymbopogon citrates (DC) Stapf & SED & Leaves & D, SS & 7 & 5 & 6 & 11 & 12 & 41 \\
\hline \multicolumn{10}{|l|}{ Polygonaceae } \\
\hline Rumex obtusifolius L. & URI & Leaves & SS & 2 & 1 & 0 & 0 & 2 & 5 \\
\hline Polygonum punctatum Elliot \& H. Lév. & URI & Whole plant & SS & 2 & 1 & 3 & 5 & 4 & 15 \\
\hline Muehlenbeckia sagittifolia (Ortega) Meisn. & $\mathrm{CDD}$ & Leaves & SS & 2 & 1 & 0 & 1 & 2 & 6 \\
\hline \multicolumn{10}{|l|}{ Pteridaceae } \\
\hline Adiantum pseudotinctum Hieron. & RSD & Leaves & SS & 1 & 1 & 0 & 2 & 1 & 5 \\
\hline \multicolumn{10}{|l|}{ Lythraceae } \\
\hline Punica granatum L. & GID & Fruit peel & SS & 1 & 0 & 0 & 1 & 1 & 3 \\
\hline \multicolumn{10}{|l|}{ Rosaceae } \\
\hline Prunus domestica L. & LXT & Leaves & $\mathrm{D}$ & 2 & 1 & 1 & 1 & 3 & 8 \\
\hline \multicolumn{10}{|l|}{ Rutaceae } \\
\hline Ruta graveolens $\mathrm{L}$. & AAI & Leaves & SS & 5 & 3 & 4 & 6 & 3 & 21 \\
\hline Citrus sinensis L. Osbeck & RSD & Leaves & $\mathrm{D}$ & 4 & 2 & 3 & 5 & 6 & 20 \\
\hline Citrus reticulata Blanco & RSD & Leaves & $\mathrm{D}$ & 1 & 0 & 0 & 1 & 4 & 6 \\
\hline \multicolumn{10}{|l|}{ Zingiberaceae } \\
\hline Zingiber officinale Roscoe & RSD & Rhizomes & $\mathrm{D}$ & 4 & 2 & 3 & 3 & 3 & 15 \\
\hline Total of citations & & & & 146 & 113 & 133 & 219 & 210 & 821 \\
\hline Shannon's index of diversity $H^{\prime}$ & & & & 5.399 & 5.166 & 5.070 & 5.305 & 5.274 & \\
\hline Eveness index $E$ & & & & 0.938 & 0.935 & 0.946 & 0.940 & 0.916 & \\
\hline
\end{tabular}

${ }^{1}$ RSD: respiratory diseases; URI: urinary infections; GID: gastrointestinal diseases; CDD: cardiac diseases; AAI: analgesics or anti-inflammatory; SED: sedative; WGC: weight control; LXT: laxative; HEA: healing; ASI: against sexual impotence.

${ }^{2}$ D: drugstore; SS: street-sellers; FM: free-markets.

Table 2. Number of medicinal plant species cited for each illness in São Gabriel (SG), Santana do Livramento (SL), Bagé (BG), Santa Maria (SM), Uruguaiana (UR) and overall.

\begin{tabular}{|l|c|c|c|c|c|c|}
\hline & \multicolumn{9}{|c|}{ Number of species cited } \\
\cline { 2 - 7 } & SG & SL & BG & SM & UR & Overall \\
\hline Respiratory diseases (RSD) & 14 & 11 & 11 & 14 & 14 & 14 \\
\hline Urinary infections (URI) & 7 & 7 & 4 & 6 & 7 & 7 \\
\hline Gastrointestinal diseases (GID) & 15 & 11 & 12 & 14 & 15 & 15 \\
\hline Cardiac diseases (CDD) & 3 & 2 & 2 & 3 & 2 & 3 \\
\hline Analgesics or anti-inflammatory (AAI) & 3 & 3 & 3 & 3 & 3 & 3 \\
\hline Sedative (SED) & 4 & 4 & 4 & 4 & 4 \\
\hline Weight control (WGC) & 3 & 3 & 1 & 2 & 3 \\
\hline Laxative (LXT) & 2 & 2 & 3 & 2 & 3 \\
\hline Healing (HEA) & 2 & 2 & 1 & 1 & 4 \\
\hline Against sexual impotence (ASI) & 1 & 1 & 0 & 1 & 2 \\
\hline
\end{tabular}


respiratory diseases with $I V_{R S D}=0.233$ and against urinary infections $I V_{U R I}=0.106$. Overall cities, the three most cited species were Cymbopogon citratus with 41 references, Baccharis trimera with 36 and Foeniculun vulgare with 33. The species against respiratory diseases with the highest importance value was Mikania glomerata $\left(I V_{\mathrm{Mg} / R S D}=0.135\right)$, against urinary infection was Euphorbia serpens $\left(I V_{\text {Ese/URI }}\right.$ $=0.284$ ), against gastrointestinal disease was Baccharis trimera $\left(V I_{B t r / G I D}=0.128\right)$, against cardiac diseases was Struthantus flexicaulis $\left(I V_{S f / C D D}=0.517\right)$, analgesic and anti-inflammatory was Sphagneticola trilobata $\left(I V_{\text {Str/AAI }}=\right.$ $0.426)$, sedative was Cymbopogon citratus $\left(I V_{\text {Ci/SED }}=0.422\right)$, for weight control was Sambucus nigra $\left(I V_{S n i / W G C}=0.565\right)$, laxative was Senna alexandrina $\left(I V_{\text {SalLXT }}=0.428\right)$ and against sexual impotence was Trichilia catigua $\left(I V_{\text {Tca/ASI }}=1.00\right)$.

\section{Diversity of medicinal plant species commercialized among cities}

The pair wise Jaccard's index of similarity revealed moderate to high correspondence of species cited in each city, ranging from $J=0.727$ between Bagé and São Gabriel to $J=0.963$ between Uruguaiana and São Gabriel (Tab. 3). Out of the 56 species cited by the informants, 36 are shared among the five cities (Fig. 2). There is no species found exclusively in a single city and from one to five species are shared among three or four cities, as visualized in the Veen's diagram (Fig. 2).

Shannon's index of diversity (Tab. 1) revealed higher diversity of species commercialized in São Gabriel ( $H^{\prime}$ = 5.399; $\left.H_{\max }=5.755\right)$, followed by Santa Maria $\left(H^{\prime}=5.305\right.$; $\left.H_{\max }=5.644\right)$, Uruguaiana $\left(H^{\prime}=5.274 ; H_{\max }=5.755\right)$, Santana do Livramento $\left(H^{\prime}=5.166 ; H_{\max }=5.524\right)$ and Bagé $\left(H^{\prime}=5.070 ; H_{\max }=5.358\right)$. The evenness index, which express the frequency the species were cited, reached $E=0.938$ in São Gabriel, $E=0.940$ in Santa Maria, $E=0.916$ in Uruguaiana, $E=0.935$ in Santana do Livramento and $E=0.946$ in Bagé.

The principal component analysis revealed $57.08 \%$ of the total variation in the first axis and $31.09 \%$ in the second axis (Fig. 3). Three cities (BG, SL and SG) formed a cluster, while Uruguaiana (UR) and Santa Maria (SM) revealed the higher differentiation in relation to the others.

The smallest estimations of knowledge richness index (KRI) were recorded for the street-seller informants in

Table 3. Jaccard's similarity index (\%) between pairs of municipalities, concerning the medicinal plant species cited by the informants.

\begin{tabular}{|l|c|c|c|c|}
\hline São Gabriel & -- & & & \\
\hline Santana do Livramento & 78.6 & -- & & \\
\hline Bagé & 72.7 & 74.0 & -- & \\
\hline Santa Maria & 88.8 & 81.1 & 78.4 & -- \\
\hline Uruguaiana & 96.3 & 81.8 & 74.1 & 85.7 \\
\hline
\end{tabular}

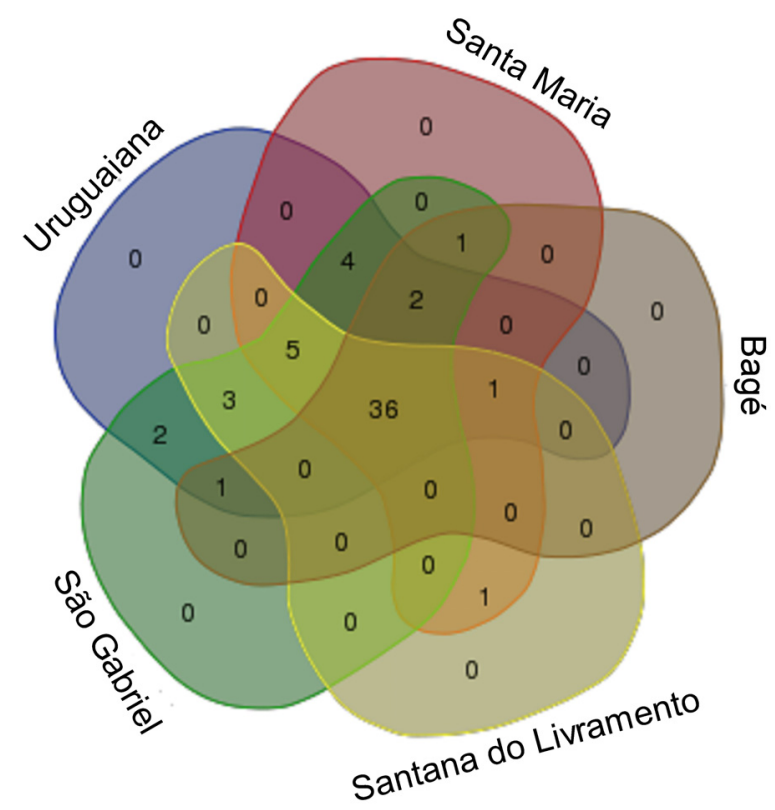

Figure 2. Venn's diagram showing the quantity of shared species among cities. Numbers within the intersections are the quantity of shared species.

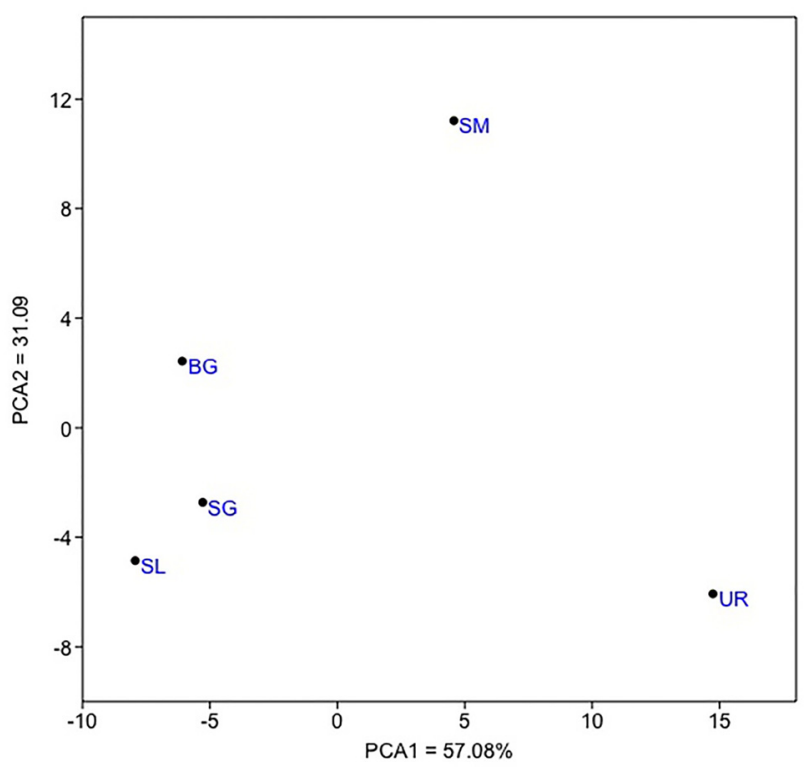

Figure 3. Principal component analysis of the cities investigated within the Pampa biome, based on the cited species and the frequency of citations of each species.

all cities (mean $K R I=0.466 \pm 0.098$; Fig. 4), suggesting that this group of informants presents the greatest richness of knowledge about medicinal plants in the Pampa biome. According to the Jaccard's index of similarity $22 \%$ $(J=0.22)$ of the species cited by street-sellers and drugstores are equivalent. The same percentage of similarity (22\%; $J=0.22)$ was observed between street-sellers and free-markets and 39\% $(J=0.39)$ between drugstores and free-markets. 


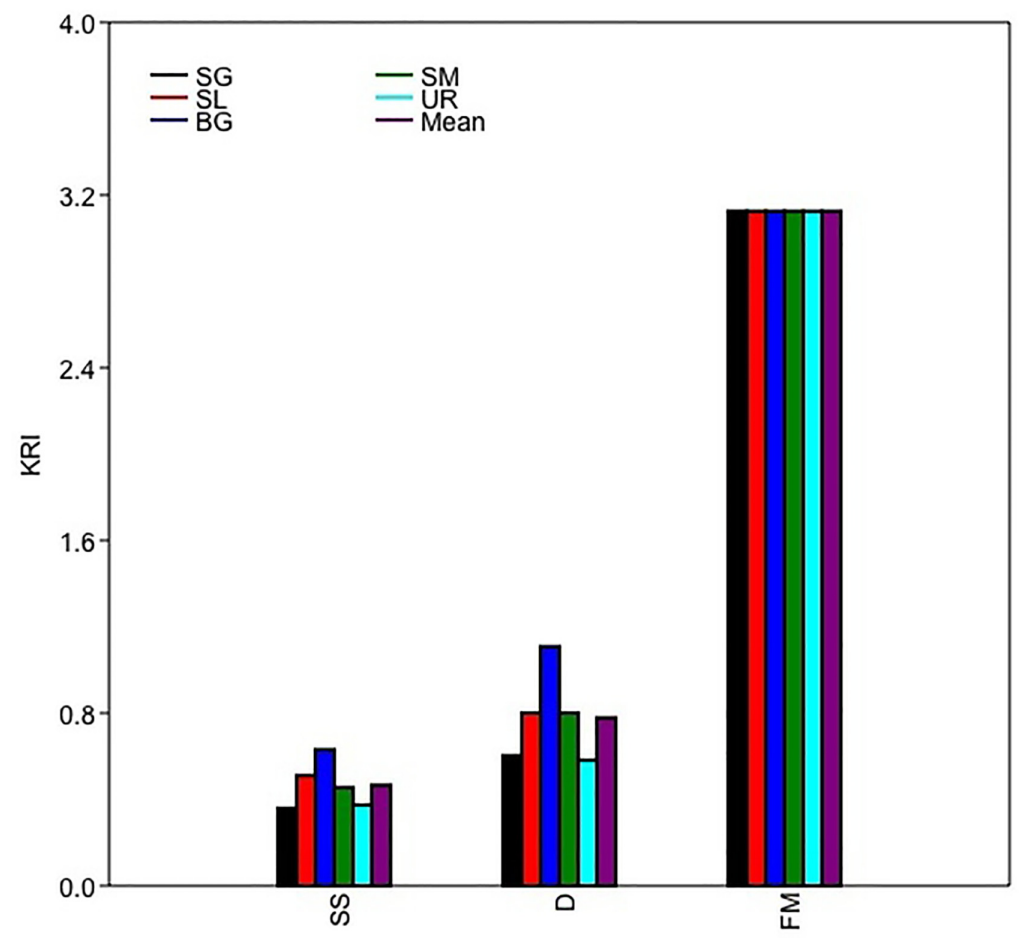

Figure 4. Values of knowledge richness index (KRI) for each city, according to the group of informants. Lower values mean the higher richness of the ethnobotanical knowledge of the group. SS = street-sellers; D = drugstores; FM = free-market. Please see the PDF version for color reference.

\section{Species with important antioxidant activity}

The samples of Sphagneticola trilobata, Malva parviflora and Struthanthus flexicaulis revealed the highest antioxidant activity according to the $\mathrm{ABTS}^{+}$radical scavenging capacity (RSA), with values of $79.19( \pm 0.007) \%$ RSA, 82.58 $( \pm 0.002) \%$ RSA and $87.59( \pm 0.002) \%$ RSA, respectively. Only Equisetum sp failed to present significant antioxidant potential, with only $10.15( \pm 0.002) \%$ RSA (Fig. $5 \mathrm{~A})$.

The ferric reducing antioxidant power (FRAP) of the plant extracts was tested, presenting the best results for Malva parviflora, Gochnatia polymorpha and Struthanthus flexicaulis. Overall species, the amount of $\mu \mathrm{M} \mathrm{Fe}[\mathrm{II}] / 100 \mathrm{~g}$ of plant extract ranged from 5,636 ( \pm 13.0$)$ for Equisetum sp to 65,416 ( \pm 23.0 ) for Malva parviflora. Also in this test, the very low values obtained for Equisetum sp demonstrated the lowest antioxidant potential (Fig. 5B).

The highest concentration of phenolic compounds was observed in Gochnatia polymorpha with 3,723.57 ( \pm 42.85$)$ mg GAE/100g of plant extract, and Struthanthus flexicaulis with $3,645.0( \pm 21.43) \mathrm{mg} \mathrm{GAE} / 100 \mathrm{~g}$ of plant extract (Fig. $5 C)$. Overall species, the amount of $\mathrm{mg} \mathrm{GAE} / 100 \mathrm{~g}$ of plant extract ranged from $327.14( \pm 3.57)$ for Equisetum sp to $3,723.57$ ( \pm 42.85$)$ for Gochnatia polymorpha.

The concentration of flavonoids ranged from 0.66 $( \pm 0.03) \mathrm{mg} \mathrm{QE} / 100 \mathrm{~g}$ of plant extract (Struthanthus flexicaulis) to $12.22( \pm 0.02) \mathrm{mg} Q \mathrm{QE} / 100 \mathrm{~g}$ of plant extract (Bauhinia forficata). The highest concentration was ob- served in Bauhinia forficata, followed by Muehlenbeckia sagittifolia with $7.21( \pm 0.10) \mathrm{mg} \mathrm{QE} / 100 \mathrm{~g}$ plant extract (Fig. 5D).

A significant positive correlation (Tab. 4) was observed between ABTS and FRAP tests $(r=0.81 ; p=0.004)$, between phenol content and ABTS test $(r=0.66 ; p=0.037)$ and between phenol content and FRAP test $(r=0.84 ; p=0.002)$. No significant correlation was observed between flavonoid contents and phenol compounds, ABTS or FRAP tests.

\section{Discussion}

\section{Diversity and species richness of commercialized medicinal plants}

The results of this study suggest that the knowledge about commercialized medicinal plant species is very conservative in the investigated area, within the Brazilian Pampa sensu stricto. Among the five studied cities, we found low differentiation concerning the commercialized medicinal plant species, with a similarity higher than $70 \%$ between pair of cities and $64.28 \%$ of the plants being cited in all five cities. Also the diversity $\left(H^{\prime}\right)$ and evenness $(E)$ of commercialized species are similar among cities. Moreover, the observed diversity of species reached more than 91.05\% of the maximal estimation of $H^{\prime}\left(H_{\max }\right)$, meaning a broad use of the cited species. Even the differentiation 


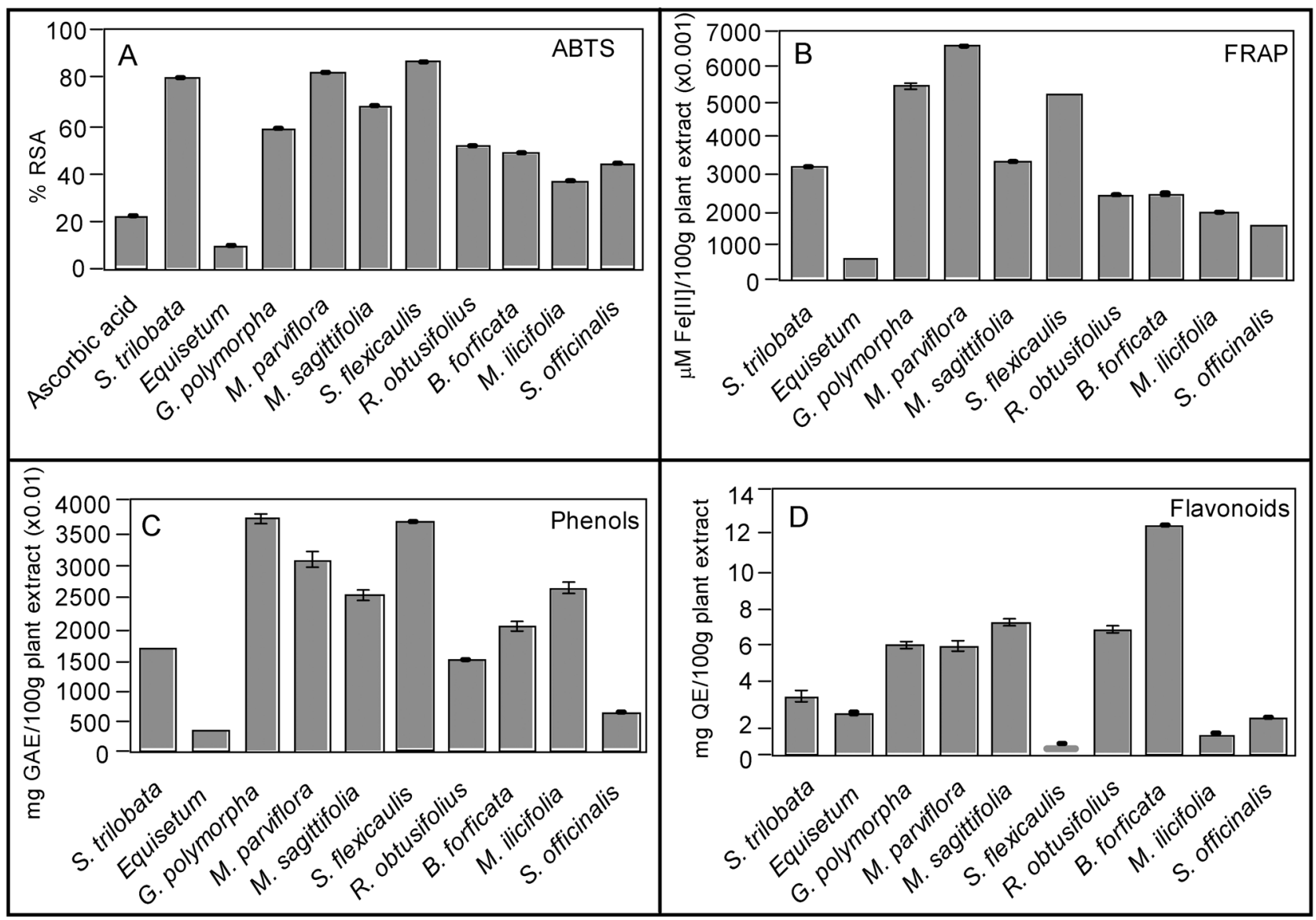

Figure 5. In vitro biochemical analyses of antioxidant activity of ten medicinal plant species commercialized in the Brazilian Pampa. A) Proportion of ABTS radical reduction expressed as \%RSA, using ascorbic acid $(20 \mu \mathrm{g} / \mathrm{mL})$ as positive control and a concentration of $10 \mathrm{mg} / \mathrm{mL}$ of plant extracts. B) Amount of reduced $\mathrm{FeSO}_{4} / 100 \mathrm{~g}$ of plant extract. C) Amount of total phenolic compounds measured as mg of GAE/100g of plant extract. D) Total flavonoid content measured as $\mathrm{mg}$ of $\mathrm{QE} / 100 \mathrm{~g}$ of plant extract.

Table 4. Linear correlation of the antioxidant estimators for the 10 medicinal plant species evaluated. Bold values highlight statistically significant correlation values $(p<0.05)$.

\begin{tabular}{|l|c|c|c|c|}
\hline & ABTS & FRAP2 & Flavonoids & Phenols \\
\hline ABTS & 1.000 & & & \\
\hline FRAP & $\mathbf{0 . 8 1 4}$ & 1.000 & & \\
\hline Flavonoids & 0.073 & 0.110 & 1.000 & \\
\hline Phenols & $\mathbf{0 . 6 6 1}$ & $\mathbf{0 . 8 4 6}$ & 0.082 & 1.000 \\
\hline
\end{tabular}

${ }^{1}$ ABTS: 2,2'-azino-bis(3-ethylbenzothiazoline-6-sulfonic acid) diammonium salt, used to measure the scavenging activity of the plant extracts

${ }^{2}$ FRAP: ferric reducing antioxidant power

of Uruguaiana and Santa Maria from the other cities revealed in the multivariate analysis is result of the higher frequency of citations of some species in these two cities, instead of the effect of the quantity or diversity of commercialized plants. Costella et al. (2013) found just 37\% of correspondence among the species cited by riverside communities of São Gabriel and Rosário do Sul, within the Brazilian Pampa. This result supports the idea of conservativeness of the knowledge about commercialization of medicinal plants, different from the plants collected aiming different conventional uses (firewood, medicinal, food and handworks).

Concerning the different groups of informants, our results reveal that street-sellers retain a much richer knowledge about medicinal plants, since only 10 out of the 56 species were not cited by this group. Opposing our expectations, only eight medicinal plant species were cited in free-markets. Free-markets are public spaces in which many kinds of products are commercialized and where cultural information exchange is expected to occur (Albuquerque et al. 2007). Different from free-markets of the Northeast Brazil (e.g. Albuquerque et al. 2007), such public spaces seems not so representative for medicinal plants in cities within the Pampa biome.Moreover, the mean knowledge richness index estimated in this study (KRI > $0.466 \pm 0.098)$ suggests lower richness knowledge of medicinal plants by the Pampean informants, in comparison to rural householders from the Caatinga biome 
$(K R I=0.285 \pm 0.55$; Araújo et al. 2012). In addition, the moderate to low similarity $(J<0.39)$ among groups of informants shows this information sharing occurs more effectively within groups than among groups. Such pattern of information sharing tends to maintain the knowledge domain of each group relatively differentiated. However, given the uneven size of the informants from each category, this aspect should be deeper investigated, increasing the coverage of the research concerning the number of informants from the street-sellers and freemarket categories.

Concerning the diversity of illnesses treated with medicinal plants, the knowledge is also very similar among cities and related to regional aspects. About $68 \%$ of the references overall cities are intended to the treatment of gastrointestinal, respiratory and urinary illnesses. The use of medicinal plants for the treatment of gastrointestinal diseases has been largely reported in ethnobotanical studies, but the high importance given to plants destined to treatment of respiratory problems and urinary infections is essentially related to the climatic conditions of the Brazilian Pampa, with rigorous winters and consequent rise of such diseases.

\section{Plant species with important antioxidant activity}

Since substantial evidences indicate that numerous human disorders and diseases present the involvement of oxidative stress, the attention of scientists has turned on the prospection and evaluation of antioxidant agents for the prevention and treatment of several diseases such as diabetes, atherosclerosis, aging, immune suppression and neurodegeneration (Saeed et al. 2012). Among the species selected for the in vitro biochemical tests, Struthanthus flexicaulis (commercialized for treatment of cardiac diseases), Gochnatia polymorpha (commercialized for treatment of respiratory diseases) and Malva parviflora (commercialized for treatment of urinary diseases) emerged as highly promising antioxidant species, according to the ABTS and FRAP tests, and the amount of total phenolics observed. The positive and statistically significant correlation between phenols content and the ABTS and FRAP tests suggests that phenolic compounds are the principal elements responsible for the antioxidant activity of these plants. On the other hand, the absence of significant correlation of flavonoid content with phenolic compounds and the ABTS and FRAP tests suggests minor participation of these compounds in the antioxidant activity of the studied plants. However, this lack of correlation of flavonoids content with phenolic compounds and the antioxidant tests needs further elucidation. At least in part, the method applied in this study may underestimate the real content of total flavonoids in the samples since the method is specific for flavones and flavonols (Cruz et al. 2014).
All selected species, although used in the people's medicine, lack studies on antioxidant activity. Struthanthus flexicaulis has been cited in some ethnobotanical studies from Northeast and Southeast regions of Brazil (Rodrigues \& Carvalho 2001), as well as in pharmacological studies testing its antibacterial capacity (Vieira et al. 2005; Oliveira et al. 2007). Similarly, Gochnatia polymorpha and Malva parviflora have been listed in some ethnobotanical studies, and anti-inflammatory (Moreira et al. 2000; Shale et al. 2005; Tadeg et al. 2005; Afolayan et al. 2010; Piornedo et al. 2011) and antispasmodic (Schlemper et al. 2011) capacities have been demonstrated for these species. The results from our study demonstrate high potential of these plant species also as sources of natural antioxidants. In addition, the significant results obtained with water extracts suggest that the conventional use of teas may be effective for the treatment of several diseases, including some not listed from the informants as ulcers, cancer and chronic diseases associated with oxidative stress.

\section{Concluding Remarks}

Medicinal plants play an important role in the healthcare of local populations in the Brazilian Pampa, with some species employed in the treatment of diseases of high importance in this region, as respiratory and urinary diseases. Considering the number of citations, the four most important medicinal plant species commercialized in the Brazilian Pampa are Cymbopogon citrates, Plectranthus barbatus, Baccharis trimera and Foeniculum vulgare. Despite the large area covered in this study, no significant difference of medicinal species and in the richness of commercialized species was identified, suggesting homogeneity of the ethnobotanical knowledge in this region. However, further studies are needed, increasing the number of informants, also including traditional groups as rural communities, "Quilombolas" and "Indigenous" groups still living within this region. Increasing the number of informants will likely increase also the richness of cited species.

In addition, considering the very promissory results concerning the antioxidant activity of Struthanthus flexicaulis, Gochnatia polymorpha and Malva parviflora, in vivo studies are required to advance the knowledge about the therapeutic uses of these species.

\section{Acknowledgements}

Authors acknowledge the financial support, grants and scholarships provided by $\mathrm{CNPq} /$ Brazil (Processes 471812/2011-0 and 474758/2012-5), CAPES, FAPERGS and Universidade Federal do Pampa (PROPESQ and PROPG). 


\section{References}

Afolayan AJ, Aboyade OM, Adedapo AAA, Sofidiya MO. 2010. Antiinflammatory and analgesic activity of the methanol extract of Malva parviflora Linn (Malvaceae) in rats. African Journal of Biotechnology 9: 1225-1229.

Albuquerque UP. 2001. The use of medicinal plants by the cultural descendants of African people in Brazil. Acta Farmacéutica Bonaerense 20: $139-144$

Albuquerque UP, Monteiro JM, Ramos MA, Amorim ELC. 2007. Medicinal and magic plants from a public market in northeastern Brazil. Journal of Ethnopharmacology 110: 76-91.

Araújo TA, Almeida ALS, Melo JG, et al. 2012. A new technique to estimate sampling sufficiency in ethnobiology studies. Journal of Ethnobiology and Ethnomedicine 8: 11.

Arvouet-Grand A, Vennat B, Pourrat A, Legret P. 1994. Standardization of a propolis extract and identification of the main constituents. Journal de Pharmacie de Belgique 49: 462-468.

Baltrušaitytė V, Venskutonis PR, Ceksteryté V. 2007. Radical scavenging activity of different floral origin honey and beebread phenolic extracts. Food Chemistry 101: 502-514.

Benzie IFF, Strain JJ. 1996. The ferric reducing ability of plasma (FRAP) as a measure of "antioxidant power": the FRAP Assay. Analytical Biochemistry 239: 70-76.

Bernard HR. 2006. Research Methods in Antropology. Qualitative and Quantitative Approachs. 4th. edn. New York, Altamira Press.

Costella E, Garcia BA, Costa LS, Corneleo NS, Schünemann AL, Stefenon VM. 2013. Anthropogenic use of gallery forests in the Brazilian Pampa. Acta Scientiarum Biological Sciences 35: 211-217.

Cruz LC, Batista JES, Zemolin APP, et al. 2014. A Study on the Quality and Identity of Brazilian Pampa Biome Honey: Evidences for Its Beneficial Effects against Oxidative Stress and Hyperglycemia. International Journal of Food Science. Vol. 2014, Article ID 470214, doi:10.1155/2014/470214.

Hammer Ø, Harper DAT, Ryan PD. 2001. Past: Paleontological Statistics Software Package for Education and Data Analysis. Palaeontologia Electronica 4: 4

Heinrich M, Gibbons S. 2001. Ethnopharmacology in drug discovery: an analysis of its role and potential contribution. Journal of Pharmacy and Pharmacology 53: 425-432.

Lemos RPM, D'Oliveira CB, Rodrigues CR, Roesch LFW, Stefenon VM. 2014. Modeling distribution of Schinus molle L. in the Brazilian Pampa: insights on vegetation dynamics and conservation of the biome. Annals of Forest Research 57: 205-214.

Moreira AS, Spitzer V, Schapoval EES, Schenkel EP. 2000. Antiinflammatory activity of extracts and fractions from the leaves of Gochnatia polymorpha. Phytotherapy Research 14: 638-640.
Oliveira DF, Pereira AC, Figueiredo HCP, et al. 2007. Antibacterial activity of plant extracts from Brazilian southeast region. Fitoterapia 78: 142-145.

Pereira V. 2014. Elementos para pensar a contribuição do Desenvolvimento Rural para conservação do bioma Pampa. Mundo Agrario 15: 28.

Piornedo RR, Souza P, Stefanello MEA, Strapasson RLB, Zampronio AR, Kassuya CAL. 2011. Anti-inflammatory activity of extracts and 11,13-dihydrozaluzanin C from Gochnatia polymorpha ssp. floccosa trunk bark in mice. Journal of Ethnopharmacology 133: 1077-1084.

Real R, Vargas JM. 1996. The Probabilistic Basis of Jaccard's Index of Similarity. Systematic Biology 45: 380-385.

Ritter MR, Silva TC, Araújo EL, Albuquerque UP. 2015. Bibliometric analysis of ethnobotanical research in Brazil (1988-2013). Acta Botanica Brasilica 29: 113-119.

Rodrigues VEG, Carvalho DA. 2001. Levantamento Etnobotânico de Plantas Medicinais no Domínio do Cerrado na Região do Alto Rio Grande - Minas Gerais. Ciência Agrotecnica 25: 102-123.

Roesch LFW, Vieira FCB, Pereira VA, et al. 2009. The Brazilian Pampa: a fragile biome. Diversity 1: 182-198.

Saeed N, Khan MR, Shabbir M. 2012. Antioxidant activity, total phenolic and total flavonoid contents of whole plant extracts Torilis leptophylla L. BMC Complementary and Alternative Medicine 12: 221.

Schlemper V, Freitas SA, Schleper SRM. 2011. Antispasmodic effects of hydroalcoholic extract from Gochnatia polymorpha sp. floccosa in the Guinea Pig Ileum. Research Journal of Medicinal Plant 5: 288-294.

Shale TL, Stirk WA, van Staden J. 2005. Variation in antibacterial and anti-inflammatory activity of different growth forms of Malva parviflora and evidence for synergism of the anti-inflammatory compounds. Journal of Ethnopharmacology 96: 325-330.

Shannon CE. 1948. A Mathematical Theory of Communication. The Bell System Technical Journal 27: 379-423, 623-656.

Singleton VL, Orthofer R, Lamuela-Raventós RM. 1998. Analysis of total phenols and other oxidation substrates and antioxidants by means of folin-ciocalteu reagent. Methods in Enzymology 299: 152-178.

Stepp JR, Moerman DE. 2001. The importance of weeds in ethnopharmacology. Journal of Ethnopharmacology 75: 19-23.

Suertegaray DMA, Silva LAP. 2009. Tchê Pampa: histórias da natureza gaúcha. In: Pillar VP et al. (ed.) Campos Sulinos: conservação e uso sustentável da biodiversidade. Ministério do Meio Ambiente. Brasília. pp. 42-59.

Tadeg H, Mohammed E, Asres K, Gebre-Mariam T. 2005. Antimicrobial activities of some selected traditional Ethiopian medicinal plants used in the treatment of skin disorders. Journal of Ethnopharmacology 100: 168-175.

Veen J. 1880. On the diagrammatic and mechanical representation of propositions and reasonings. Philosophical Magazine Series 5 9:1-18.

Vieira OMC, Santos MH, Silva GA, Siqueira AM. 2005. Atividade antimicrobiana de Struthanthus vulgaris (erva-de-passarinho). Brazilian Journal of Pharmacognosy 15: 149-154. 